\title{
Tectonic boundary between the Sanbagawa belt and the Shimanto belt in central Shikoku, Japan
}

\begin{abstract}
Kazumasa Aoki*, Tsuyoshi Iizuka**, Takafumi Hirata*, Shigenori Maruyama* and Masaru Terabayashi***

Received May 24, 2006.

Accepted March 12, 2007

* Department of Earth and Planetary Sciences, Tokyo Institute of Technology, Ookayama Meguro-ku, Tokyo 152-8551, Japan

** Earthquake Research Institute, The University of Tokyo, Yayoi, Bunkyo-ku, Tokyo 1130032, Japan

*** Department of Safety Systems Construction Engineering, Kagawa University, Hayashi-cho, Takamatsu, Kagawa 761-0396, Japan

Corresponding author: K. Aoki, kazumasa@geo.titech.ac.jp

Abstract

In order to make it clear the mode of occurrence of the Sanbagawa belt, we carried out in situ U-Pb isotope analyses of igneous zircon grains from the Oboke area that was a type area of the Sanbagawa belt in central Shikoku, Japan. Analyzed igneous zircons were separated from psammitic schist in the Minawa and Kawaguchi Formations and from igneous cobbles in the Koboke Formation. Spot analyses were performed on the laser ablation-inductively coupled plasma mass spectrometer (LA-ICP-MS). The youngest U-Pb ages of zircon grains from the Koboke Formation and the Kawaguchi Formation showed $92 \pm 4$ $\mathrm{Ma}$ and $82 \pm 11 \mathrm{Ma}$, respectively. On the other hand, zircons from the Minawa Formation yielded remarkably older ages clustered around 1900-1800 Ma. There is a large chronological gap between protolith sedimentary clasts of the Minawa and those of the other two formations. The protolith sedimentary ages of the Sanbagawa belt have been well constrained as older than $130 \mathrm{Ma}$ based on fossil and U-Pb isotopic ages. The peak metamorphism occurred in 120-110 Ma. Therefore, both Koboke and Kawaguchi Formations must not belong to the Sanbagawa belt, because the timing of formation of accretionary complex must be later than $92 \pm 4 \mathrm{Ma}$ for the Koboke Formation and $82 \pm 11 \mathrm{Ma}$ for the Kawaguchi Formation. Both the Koboke and Kawaguchi Formations correspond to the late Cretaceous accretionary complex, and they are equivalent to the Northern Shimanto belt. The tectonic boundary between the Sanbagawa and the Northern Shimanto belts is reverse fault and the Northern Shimanto belt appears as a tectonic window in the Sanbagawa belt, central Shikoku. The whole package of the Sanbagawa and underlying Shimanto belts are deformed by the secondary fault movement and doming after the tectonic juxtaposition at the midcrustal levels.
\end{abstract}

Key words: Geotectonic subdivision, Tectonic boundary, Sanbagawa metamorphism, Sanbagawa belt, Northern Shimanto belt, Oboke area, LA-ICP$\mathrm{MS}, \mathrm{U}-\mathrm{Pb}$ age, Igneous zircon

\section{Introduction}

Mode of occurrence of high-P/T regional metamorphic belt is a key to understand the tectonic evolution of deepseated accretionary complex along the subduction zone. Thermobaric structure of the high-pressure and/or ultrahigh-pressure metamorphic belts have been examined to clarify their exhumation process (e.g. Terabayashi et al., 1996; Ota et al., 2000; 2004). Correlation with surrounding geologic units is also important to verify the exhumation tectonics, and high-P/T regional metamorphic belts are bounded by a subhorizontal thrust on the bottom and by a subhorizontal normal fault on the top (e.g. Maruyama et al., 1996). It has been well documented from SW Japan that high-P/T metamorphic belts are distributed in the core of accretionary complexes as a subhorizontal thin slice (e.g. Isozaki and Maruyama, 1991). The Cretaceous Sanbagawa belt is one of the typical high-P/T metamorphic belts in the world. The constituent rocks are products of tectonic accretion during subduction of oceanic plates in the Jurassic to Cretaceous periods (e.g. Isozaki and Itaya, 1990; Okamoto et al., 2000; Terabayashi et al., 2004). In central Kii Peninsula, Sasaki and Isozaki (1992) discovered a thrust boundary between the Sanbagawa belt and the underlying Shimanto belt, and Masago et al. (2005) determined a sense of shear of the thrust by kinematic analyses.

In central Shikoku, Kawato et al. (1991) identified the 


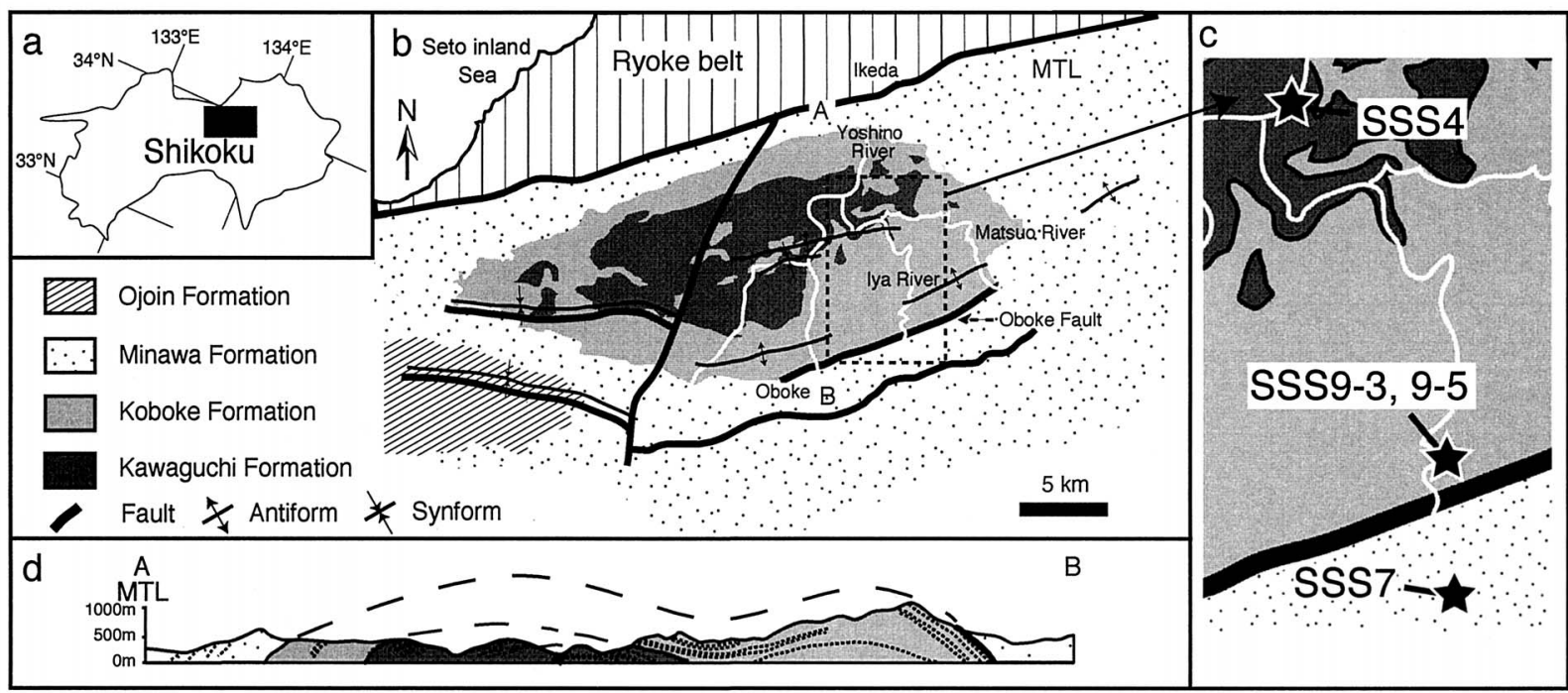

Fig. 1. (a) Index map of the central Shikoku, Japan. (b) Geological map of the Oboke area in central Shikoku (modified after Kenzan Research Group, 1984). MTL: Median Tectonic Line. (c) Sample locality of the Oboke area. (d) A N-S cross-section of the Oboke area (modified after Kojima and Mitsuno, 1966).

upper tectonic boundary of the Sanbagawa metamorphic rocks as the normal fault, on which the Jurassic Chichibu belt rests. However, it is still controversial for identification of the bottom boundary in Shikoku, there are no direct observations about the relationship between the Sanbagawa belt and underlying geological unit. Structural analysis of the Sanbagawa belt in Shikoku is important because full sequence of the Sanbagawa metamorphic rocks, including the highest grade eclogite and the lowest grade schist, is widely distributed. The Oboke area in central Shikoku has been ascribed as the lowest sequence of the belt, and metamorphic grade has been recognized as the lowest (the pumpellyite-actlinolite facies to the blueschist facies, 5-6 kbar, 250 $300{ }^{\circ} \mathrm{C}$ : Banno and Sakai, 1989). In the Oboke area, the standard lithostratigraphy of the Sanbagawa belt was established (e.g. Kojima, 1951), and is divided into three formations according to the lithological succession of protolith, the Minawa, Koboke and Kawaguchi Formations in structurally descending order (Fig. 1). All of them have been regarded as the Sanbagawa schists, because these are foliated enough to be identified as schist. Hara et al. (1990) suggested that the structural discontinuity exists between the Besshi unit including the Minawa Formation and the Oboke unit composed of the Koboke and Kawaguchi Formations.

In central Kii Peninsula, Rb-Sr whole rock isochron age of $77.1 \pm 6.1 \mathrm{Ma}$ has been obtained from phyllites in the Shimanto belt (Shibata et al., 1988). In the Oboke area, radiometric Ar-Ar whole rock and K-Ar phengite ages of 77-63 Ma have been obtained from the Koboke Formation (Itaya and Takasugi, 1988; Takasu and Dallmeyer,
1990). Thus, the metamorphic age and the tectonic feature of the Shimanto belt in Kii Peninsula are very similar to those of the Oboke area. Hence, we have serious reservations about the ascription of the Oboke area. Indeed, some authors have already argued that the Koboke and Kawaguchi Formations may represent underplated deeper facies of the Cretaceous Shimanto accretionary complex (e.g. Isozaki and Maruyama, 1991; Kiminami et al., 1999)

To solve the debate, it is critical to find out microfossil or to get high-resolution age determination of zircon to document the depositional age constraints. However, nobody has succeeded to report any occurrence of microfossils in the Oboke area because of extensive ductile deformation.

Detrital zircon is thus the best way to identify the origin of the schist distributed in the Oboke area. By these reasons, we separated igneous zircons from each formation and carried out U-Pb analyses using a laser ablationinductively coupled plasma-mass spectrometer (LA-ICPMS) in Tokyo Institute of Technology. On the basis of the results, we discuss the ascription of the Oboke area and the mode of occurrence of the Sanbagawa belt.

\section{Geological outline}

The Sanbagawa belt in the Oboke area of central Shikoku has been occupied by three formations from top to the bottom: Minawa Formation, Koboke Formation and Kawaguchi Formation, based on lithological assemblages (Kojima, 1951; Kenzan Research Group, 1984). These three formations are gently folded to yield two antiforms and a synform due to doming (Fig. 1). The Minawa and 
the Kawaguchi Formations are composed mainly of pelitic schist with interlayered psammitic schist, and minor basic and siliceous schists. On the other hand, constituent rocks of the Koboke Formation are dominantly psammitic schist with subordinate amount of pelitic, siliceous and conglomeratic schist (Kojima, 1951; Kenzan Research Group, 1984). These formations record the chlorite zone metamorphism (Banno and Sakai, 1989).

\section{Sample description}

We have systematically collected psammitic schists and igneous cobbles in conglomeratic schist along the Yoshino River and the Iya River from the stratigraphically lowest Kawaguchi Formation through the Koboke Formation to the topmost Minawa Formation. After the examination of twenty-four samples under the microscope, four samples were selected for age determination (Fig. 1.c). These are psammitic schist from the Kawaguchi Formation (sample no. SSS4) and the Minawa Formation (sample no. SSS7) and two igneous cobbles from the Koboke Formation (sample no. SSS9-3 and SSS9-5).

\section{Kawaguchi psammitic schist}

The psammitic schist (SSS4) is composed mainly of quartz, albite, chlorite and phengite. Coarse-grained quartz and albite show granular or irregular shape (up to $0.7 \mathrm{~mm}$ in diameter). Fine-grained quartz and albite show a granoblastic texture (up to $0.2 \mathrm{~mm}$ in diameter). The foliation and mineral lineation are defined by chlorite (longer dimension $0.8 \mathrm{~mm}$ ) and fine-grained phengite that shows a lepidoblastic texture. Accessory minerals are titanite, zircon and apatite. Those were originally detrital mineral particles, and were recrystallized.

\section{Koboke igneous cobbles}

Six cobble samples were collected from conglomeratic layers in Koboke Formation. These cobbles have ellipsoidal shape on outcrop. Five samples are pale green in color (quartz porphyritic rock) and one sample is white in color (granitic rock). The average size is about $10 \times 10 \times$ $7 \mathrm{~cm}$ (maximum size is about $20 \times 20 \times 10 \mathrm{~cm}$ ). The granite cobble (SSS9-3: $10 \times 10 \times 5 \mathrm{~cm}$ in dimension) is holocrystalline, and consists mainly of quartz and plagioclase (up to $1 \mathrm{~mm}$ in diameter) with accessory rutile, titanite, zircon and apatite. Minor sulfide and Fe-oxides are also present. No mafic igneous silicate and K-feldspar remain.

The granite porphyry cobble (SSS9-5: $20 \times 10 \times 10 \mathrm{~cm}$

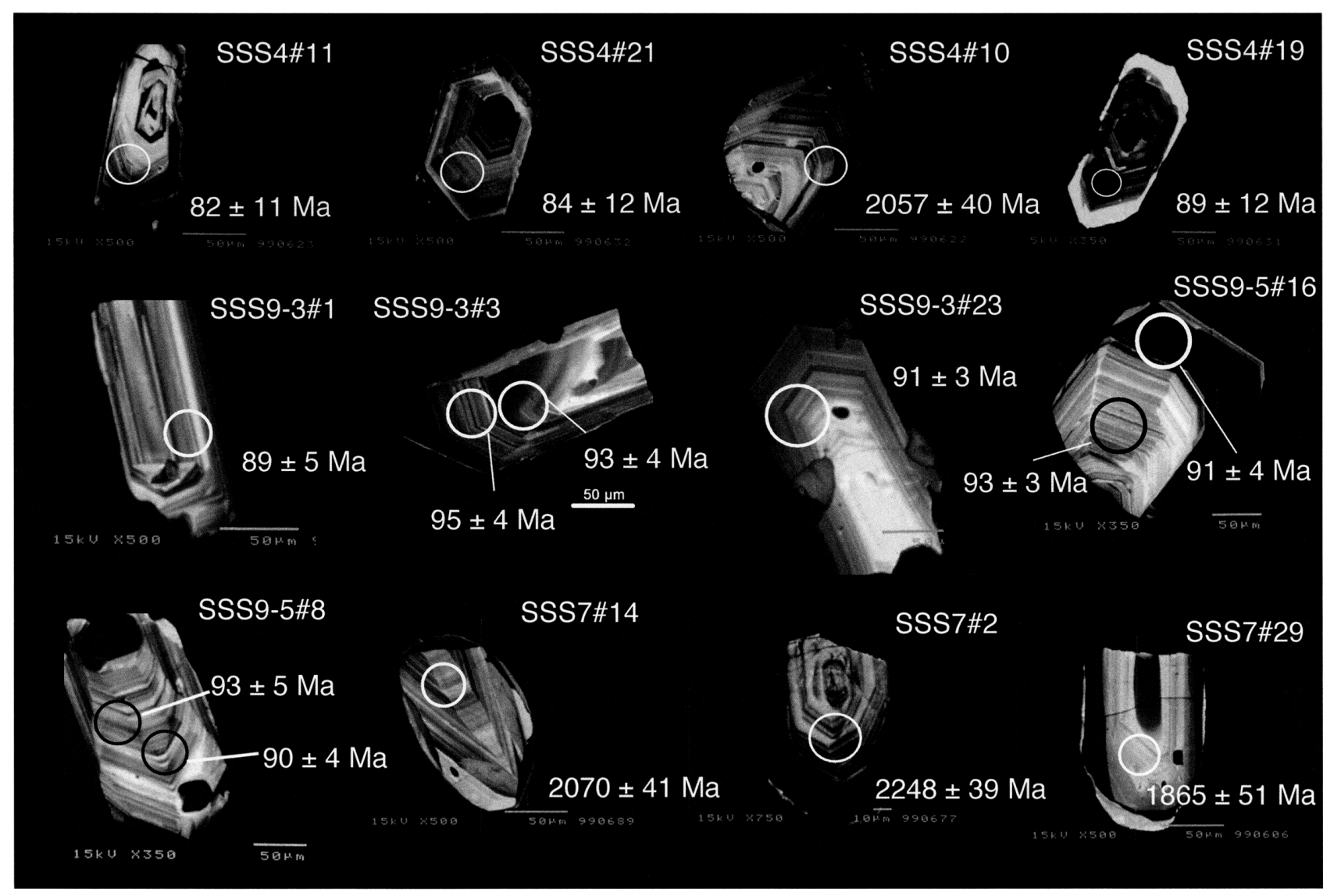

Fig. 2. Representative CL images of the analyzed zircons. The U-Pb ages are shown for each LA-ICP-MS analysis spot. Also shown are the spots (ca. $32 \mu$ m diameter) of LA-ICP-MS analysis. 
Table. 1. LA-ICP-MS U-Pb isotopic analytical data for zircons from psammitic schist (Kawaguchi and Minawa Formations)

\begin{tabular}{|c|c|c|c|c|c|c|c|c|}
\hline Formation & Sample & $\begin{array}{c}\text { Internal } \\
\text { structure }^{+}\end{array}$ & $\mathrm{U}(\mathrm{ppm})$ & Th (ppm) & ${ }^{8204} \mathrm{~Pb} /{ }^{206} \mathrm{~Pb}$ & ${ }^{206} \mathrm{~Pb}^{\star}{ }^{238} \mathrm{U}(2 \sigma)$ & ${ }^{207} \mathrm{~Pb}^{\star} /{ }^{206} \mathrm{~Pb}^{\star}(2 \sigma)$ & U-Pb age (Ma) \\
\hline Kawaguchi & SSS4 \#6 S1 & osc & 197 & 576 & 0.00021 & $0.0310 \pm 0.0043$ & $0.0486 \pm 0.0073$ & $197 \pm 27$ \\
\hline Kawaguchi & SSS4 \#9 S1 & osc & 119 & 110 & 0.00018 & $0.2168 \pm 0.0301$ & $0.1108 \pm 0.0029$ & $1812 \pm 47$ \\
\hline Kawaguchi & SSS4 \#10 S1 & osc & 106 & 170 & 0.00003 & $0.3833 \pm 0.0532$ & $0.1270 \pm 0.0029$ & $2057 \pm 40$ \\
\hline Kawaguchi & SSS4 \#11 S1 & osc & 135 & 325 & $<0.000005$ & $0.0128 \pm 0.0018$ & $0.0458 \pm 0.0042$ & $82 \pm 11$ \\
\hline Kawaguchi & SSS4 \#13 S1 & osc & 181 & 143 & 0.00003 & $0.1314 \pm 0.0182$ & $0.1063 \pm 0.0028$ & $1737 \pm 49$ \\
\hline Kawaguchi & SSS4 \#14 S1 & osc & 144 & 29 & $<0.000005$ & $0.2763 \pm 0.0384$ & $0.1134 \pm 0.0026$ & $1855 \pm 42$ \\
\hline Kawaguchi & SSS4 \#16 S1 & osc & 242 & 296 & 0.00110 & $0.0166 \pm 0.0023$ & $0.0432 \pm 0.0158$ & $106 \pm 15$ \\
\hline Kawaguchi & SSS4 \#19 S1 & osc & 310 & 538 & $<0.000005$ & $0.0139 \pm 0.0019$ & $0.0463 \pm 0.0029$ & $89 \pm 12$ \\
\hline Kawaguchi & SSS4 \#21 S1 & osc & 256 & 397 & $<0.000005$ & $0.0132 \pm 0.0018$ & $0.0489 \pm 0.0033$ & $84 \pm 12$ \\
\hline Kawaguchi & SSS4 \#22 S1 & osc & 113 & 217 & $<0.000005$ & $0.0135 \pm 0.0019$ & $0.0500 \pm 0.0047$ & $87 \pm 12$ \\
\hline Kawaguchi & SSS4 \#26 S1 & osc & 66 & 96 & $<0.000005$ & $0.0134 \pm 0.0019$ & $0.0595 \pm 0.0066$ & $86 \pm 12$ \\
\hline Kawaguchi & SSS4 \#27 S1 & osc & 56 & 169 & 0.00225 & $0.0382 \pm 0.0055$ & $0.0181 \pm 0.0294$ & $242 \pm 34$ \\
\hline Kawaguchi & SSS4 \#28 S1 & osc & 76 & 95 & $<0.000005$ & $0.0151 \pm 0.0021$ & $0.0450 \pm 0.0050$ & $97 \pm 13$ \\
\hline Kawaguchi & SSS4 \#29 S1 & osc & 183 & 254 & 0.00028 & $0.0135 \pm 0.0019$ & $0.0445 \pm 0.0165$ & $87 \pm 12$ \\
\hline Minawa & SSS7 \#2 S1 & osc & 114 & 222 & 0.00004 & $0.3652 \pm 0.0566$ & $0.1417 \pm 0.0032$ & $2248 \pm 39$ \\
\hline Minawa & SSS7 \#3 S1 & osc & 29 & 62 & 0.00038 & $0.5834 \pm 0.0906$ & $0.2681 \pm 0.0065$ & $3295 \pm 38$ \\
\hline Minawa & SSS7 \#6 S1 & osc & 267 & 95 & $<0.000005$ & $0.2933 \pm 0.0455$ & $0.1126 \pm 0.0024$ & $1842 \pm 38$ \\
\hline Minawa & Sss7 \#6 S2 & osc & 260 & 102 & 0.00001 & $0.2658 \pm 0.0412$ & $0.1112 \pm 0.0024$ & $1820 \pm 39$ \\
\hline Minawa & SSS7 \#9 S1 & osc & 132 & 121 & $<0.000005$ & $0.3226 \pm 0.0500$ & $0.1221 \pm 0.0028$ & $1987 \pm 41$ \\
\hline Minawa & SSS7 \#13 S1 & osc & 153 & 62 & $<0.000005$ & $0.3171 \pm 0.0492$ & $0.1139 \pm 0.0026$ & $1862 \pm 41$ \\
\hline Minawa & SSS7 \#14 S1 & osc & 105 & 109 & $<0.000005$ & $0.3650 \pm 0.0566$ & $0.1280 \pm 0.0030$ & $2070 \pm 41$ \\
\hline Minawa & SSS7 \#17 S1 & osc & 95 & 132 & 0.00007 & $0.3374 \pm 0.0523$ & $0.1123 \pm 0.0028$ & $1837 \pm 45$ \\
\hline Minawa & SSS7 \#17 S2 & osc & 118 & 121 & $<0.000005$ & $0.3278 \pm 0.0508$ & $0.1144 \pm 0.0027$ & $1870 \pm 43$ \\
\hline Minawa & SSS7 \#20 S1 & osc & 213 & 607 & $<0.000005$ & $0.3452 \pm 0.0535$ & $0.1135 \pm 0.0024$ & $1856 \pm 39$ \\
\hline Minawa & SSS7 \#22 S1 & osc & 24 & 40 & $<0.000005$ & $0.5365 \pm 0.0833$ & $0.1612 \pm 0.0046$ & $2468 \pm 48$ \\
\hline Minawa & SSS7 \#26 S1 & osc & 28 & 37 & 0.00016 & $0.3295 \pm 0.0512$ & $0.1151 \pm 0.0039$ & $1881 \pm 61$ \\
\hline Minawa & SSS7 \#29 S1 & osc & 56 & 106 & 0.00003 & $0.3033 \pm 0.0471$ & $0.1140 \pm 0.0033$ & $1865 \pm 51$ \\
\hline Minawa & SSS7 \#36 S1 & osc & 89 & 51 & $<0.000005$ & $0.3637 \pm 0.0564$ & $0.1141 \pm 0.0028$ & $1866 \pm 44$ \\
\hline
\end{tabular}

All errors are quoted at $2 \sigma$ level. ${ }^{*}$ Common $\mathrm{Pb}$ corrected using ${ }^{204} \mathrm{~Pb}$.

No common $\mathrm{Pb}$ correction has been applied to analyses for which the corrected ratio is within $2 \sigma$ of the uncorrected ratio.

${ }^{\dagger}$ Internal structures in cathodoluminescence images - osc oscillatory zoning.

${ }^{206} \mathrm{~Pb} /{ }^{238} \mathrm{U}(2 \sigma)$ age is indicated by boldface ${ }^{207} \mathrm{~Pb} /{ }^{206} \mathrm{~Pb}(2 \sigma)$ age is indicated by fineface

in dimension) preserves porphyitic texture. Phenocyst minerals are quartz and plagioclase (up to $1 \mathrm{~mm}$ in diameter). Groundmass minerals are quartz, phengite and plagioclase. Sulfide and Fe-oxides are also present. Accessory minerals are zircon, apatite, rutile and titanite. Secondary minerals are chlorite, carbonate and phengite. No mafic igneous silicate and K-feldspar remain.

\section{Minawa psammitic schist}

The psammitic schist (SSS7) consists mainly of quartz, albite, phengite, chlorite and opaque minerals. Finegrained quartz and albite (up to $0.2 \mathrm{~mm}$ in diameter) show granoblastic texture. Coarse-grained quartz and albite (about $0.8 \mathrm{~mm}$ in diameter) show granular and irregular shapes. Matrix chlorite and phengite (about 0.4 $\mathrm{mm}$ in length) show lepidoblastic texture. Minor epidote, calcite, tourmaline and zircon are also recognized. The foliation and mineral lineation are composed of chlorite and phengite.

\section{Analytical procedure}

Zircon grains were separated from $\sim 3 \mathrm{~kg}$ rock samples using standard crushing, magnetic separator and heavyliquid techniques. Thirty to fifty zircon grains from each sample were mounted in epoxy and were polished. We checked the internal structures of the zircons and the presence of inclusions using transmitted and reflected optical microscopy and cathodoluminescence (CL) imaging. Moreover, in order to determine the timing of magmatic event rather than metamorphic event, sites within grains showing oscillatory zoning structure, which is very common in igneous zircons (Corfu et al., 2003), were selected for analyses (Fig. 2).

The U-Pb isotope analyses were performed on a Thermo-Elemental VG PlasmaQuad 2 quadrupole-based ICPMS equipped with a S-option interface and a MicroLas production (Göttingen, Germany) GeoLas 200 CQ laser ablation system utilizing a Lambda Physik (Göttingen, Germany) COMPex 102 ArF excimer laser at the Tokyo Institute of Technology (Iizuka and Hirata, 2004). Helium gas was flushed into the ablation cell, minimizing aerosol deposition around the ablation pit and improving transport efficiency (Eggin et al., 1998). In order to improve the stability of the signals, a gas expansion chamber was inserted between the ablation cell and the ICP ion source (Tunheng and Hirata, 2004).

$\mathrm{U}-\mathrm{Pb}$ isotopic data were obtained from single ablation 
Table. 2. LA-ICP-MS U-Pb isotopic analytical data for zircons from igneous cobbles (Koboke Formation)

\begin{tabular}{|c|c|c|c|c|c|c|c|c|c|}
\hline Formation & Sample & Internal & $\mathrm{U}(\mathrm{ppm})$ & Th (ppm) & $\frac{8204}{8{ }^{204} / 206} \mathrm{~Pb}$ & ${ }^{206} \mathrm{~Pb}^{\star} / 2^{238} \mathrm{U}(2 \sigma)$ & ${ }^{207} \mathrm{~Pb}^{\star} /{ }^{206} \mathrm{~Pb}^{\star}(2 \sigma)$ & $\mathrm{U}-\mathrm{Pb}$ & age $(\mathrm{Ma})$ \\
\hline Koboke & SSS9-3 \#1 S1 & osc & 150 & 378 & 0.00480 & $0.0140 \pm 0.0008$ & $0.0531 \pm 0.0384$ & 89 & \pm 5 \\
\hline Koboke & sss9-3 \#3 S1 & osc & 93 & 208 & $<0.000005$ & $0.0145 \pm 0.0006$ & $0.0529 \pm 0.0039$ & 93 & \pm 4 \\
\hline Koboke & sss9-3 \#3 S2 & osc & 200 & 444 & $<0.000005$ & $0.0149 \pm 0.0006$ & $0.0465 \pm 0.0026$ & 95 & \pm 4 \\
\hline Koboke & sss9-3 \#9 S1 & osc & 335 & 630 & $<0.000005$ & $0.0149 \pm 0.0005$ & $0.0482 \pm 0.0022$ & 95 & \pm 3 \\
\hline Koboke & SSS9-3 \#10 S1 & osc & 147 & 344 & 0.00095 & $0.0141 \pm 0.0006$ & $0.0484 \pm 0.0219$ & 90 & \pm 4 \\
\hline Koboke & sss9-3 \#19 S1 & osc & 225 & 754 & 0.00103 & $0.0143 \pm 0.0006$ & $0.0384 \pm 0.0197$ & 92 & \pm 4 \\
\hline Koboke & sss9-3 \#21 S1 & osc & 142 & 409 & 0.00068 & $0.0143 \pm 0.0007$ & $0.0440 \pm 0.0250$ & 92 & \pm 4 \\
\hline Koboke & SSS9-3 \#23 S1 & osc & 181 & 416 & $<0.000005$ & $0.0142 \pm 0.0005$ & $0.0534 \pm 0.0030$ & 91 & \pm 3 \\
\hline Koboke & SSS9-3 \#25 S1 & osc & 255 & 593 & $<0.000005$ & $0.0143 \pm 0.0005$ & $0.0475 \pm 0.0024$ & 92 & \pm 3 \\
\hline Koboke & SSS9-3 \#27 S1 & osc & 216 & 451 & 0.00097 & $0.0143 \pm 0.0006$ & $0.0409 \pm 0.0160$ & 91 & \pm 4 \\
\hline Koboke & Mean (2 S.D.) & & & & & $0.0144 \pm 0.0006$ & $0.0473 \pm 0.0102$ & 92 & \pm 4 \\
\hline Koboke & SSS9-5 \#1 S1 & osc & 124 & 207 & $<0.000005$ & $0.0141 \pm 0.0004$ & $0.0474 \pm 0.0033$ & 90 & \pm 3 \\
\hline Koboke & SSS9-5 \#6 S1 & osc & 227 & 324 & $<0.000005$ & $0.0152 \pm 0.0005$ & $0.0498 \pm 0.0025$ & 97 & \pm 3 \\
\hline Koboke & SSS9-5 \#8 S1 & osc & 126 & 220 & 0.00083 & $0.0140 \pm 0.0006$ & $0.0377 \pm 0.0277$ & 90 & \pm 4 \\
\hline Koboke & SSS9-5 \#8 S2 & osc & 103 & 164 & 0.00077 & $0.0146 \pm 0.0007$ & $0.0374 \pm 0.0322$ & 93 & \pm 5 \\
\hline Koboke & SSS9-5 \#9 S1 & osc & 352 & 462 & 0.00083 & $0.0150 \pm 0.0005$ & $0.0518 \pm 0.0125$ & 96 & \pm 3 \\
\hline Koboke & SSS9-5 \#15 S1 & osc & 369 & 561 & 0.00027 & $0.0145 \pm 0.0004$ & $0.0451 \pm 0.0086$ & 93 & \pm 3 \\
\hline Koboke & SSS9-5 \#16 S1 & osc (core) & 105 & 214 & 0.00065 & $0.0145 \pm 0.0007$ & $0.0347 \pm 0.0297$ & 93 & \pm 4 \\
\hline Koboke & SSS9-5 \#16 S2 & osc (rim) & 187 & 316 & 0.00337 & $0.0143 \pm 0.0006$ & $0.0311 \pm 0.0258$ & 91 & \pm 4 \\
\hline Koboke & SSS9-5 \#21 S1 & osc & 122 & 208 & 0.00320 & $0.0149 \pm 0.0008$ & $0.0687 \pm 0.0362$ & 95 & \pm 5 \\
\hline Koboke & SSS9-5 \#27 S1 & osc & 337 & 483 & 0.00100 & $0.0154 \pm 0.0007$ & $0.0354 \pm 0.0115$ & 98 & \pm 4 \\
\hline Koboke & SSS9-5 \#25 S1 & osc & 414 & 894 & 0.00029 & $0.0142 \pm 0.0006$ & $0.0496 \pm 0.0099$ & 91 & \pm 4 \\
\hline Koboke & SSS9-5 \#28 S1 & osc & 323 & 340 & 0.00001 & $0.0148 \pm 0.0006$ & $0.0538 \pm 0.0023$ & 95 & \pm 4 \\
\hline Koboke & Mean (2 S.D.) & & & & & $0.0146 \pm 0.0006$ & $0.0452 \pm 0.0168$ & 94 & \pm 4 \\
\hline \multicolumn{10}{|c|}{ All errors are quoted at $2 \sigma$ level. ${ }^{*}$ Common $\mathrm{Pb}$ corrected using ${ }^{204} \mathrm{~Pb}$. } \\
\hline \multicolumn{10}{|c|}{$\begin{array}{l}\text { No common } \mathrm{Pb} \text { correction has been applied to analyses for which the corrected ratio is within } 2 \sigma \text { of the uncorrected ratio. } \\
{ }^{\dagger} \text { Internal structures in cathodoluminescence images - osc oscillatory zoning. } \\
{ }^{206} \mathrm{~Pb} /{ }^{38} \mathrm{U}(2 \sigma) \text { age is indicated by boldface. }\end{array}$} \\
\hline
\end{tabular}

pits $(\sim 32 \mu \mathrm{m})$ with laser repetition rates of $6 \mathrm{~Hz}$, a laser ablation time of $15 \mathrm{sec}$ and laser energy density of $5 \mathrm{~J} / \mathrm{cm}^{2}$ at the sample surface. The instrumental bias for the ${ }^{206} \mathrm{~Pb} /{ }^{238} \mathrm{U}$ ratio was corrected by normalizing against SL13 (572 Ma). Common $\mathrm{Pb}$ was corrected using ${ }^{204} \mathrm{~Pb}$. The isobaric interference of ${ }^{204} \mathrm{Hg}$ on ${ }^{204} \mathrm{~Pb}$ was corrected by monitoring ${ }^{202} \mathrm{Hg}$. In order to reduce the isobaric interference of ${ }^{204} \mathrm{Hg}$, a Hg-trap device using an activated charcoal filter was applied to the Ar make-up gas before mixing with He carrier gas (Hirata et al., 2005). No common Pb correction has been applied to analyses that the corrected ratio is within analytical uncertainty of uncorrected ratio. Analytical uncertainties combine the counting statistics and the reproducibility of the standard analyses (NIST SRM 610 for ${ }^{207} \mathrm{~Pb} /{ }^{206} \mathrm{~Pb}$ and the standard zircons for ${ }^{206} \mathrm{~Pb} /{ }^{238} \mathrm{U}$, respectively), added in quadrature. Because ${ }^{207} \mathrm{~Pb}$ concentrations of NIST SRM 610 is higher than that of analyzed zircon samples, a further $1 \%$ uncertainty is assigned to the errors of the ${ }^{207} \mathrm{~Pb} /{ }^{206} \mathrm{~Pb}$ isotope ratios.

\section{Zircon U-Pb ages}

The results of analysis are listed in Tables 1 and 2, and are graphically presented on Tera-Wasserburg (TW) diagrams with $2 \sigma$ errors (Fig. 3), histograms of apparent zircon age (Fig. 4) and Th-U diagram (Fig. 5). U-Pb age in Tables 1 and 2 and Figure 4 represents ${ }^{207} \mathrm{~Pb} /{ }^{206} \mathrm{~Pb}$ age for zircons where ${ }^{207} \mathrm{~Pb}$ analytical intensities are higher than $1000 \mathrm{cps}$, and ${ }^{206} \mathrm{~Pb} /{ }^{238} \mathrm{U}$ age for other zircons.

\section{Kawaguchi Formation}

Fourteen spots were analyzed from fourteen zircon grains separated from the Kawaguchi Formation (SSS4). The data from oscillatory-zoned parts are plotted on the concordia curve in TW diagram. These data show three clusters of ages; (1) Proterozoic ages of 2100-1700 Ma (SSS4 \#9, \#10, \#13 and \#14), (2) 250-200 Ma (SSS4\#1 and \#27), and (3) 100-80 Ma (SSS4 \#11, \#16, \#19, \#21, \#22, \#26, \#27 and \#29) (Table 1, Figs. 3.a, 4). The youngest group predominates more than $55 \%$, and the data are mostly concordant. Analyzed zircons have high Th/U ratios from 0.20 to 3.02 (Fig. 5), within the range of igneous zircons (Th/U >0.1; Hoskin and Black, 2000). $\mathrm{Th} / \mathrm{U}$ ratios of the analyzed zircons as well as oscillatory zoning structure clearly indicate their igneous origin. It should be noted that these zircons are detrital in origin, therefore the distribution and frequency of the zircon age means that the source region was composed dominantly of 100-80 Ma igneous rocks, with minor 250-200 Ma and 2100-1700 Ma igneous rocks.

\section{Koboke Formation}

Two igneous cobbles from conglomeratic schist were analyzed. Ten spots were analyzed from nine zircon grains of the granite cobble (SSS9-3). The data from oscillatory- 

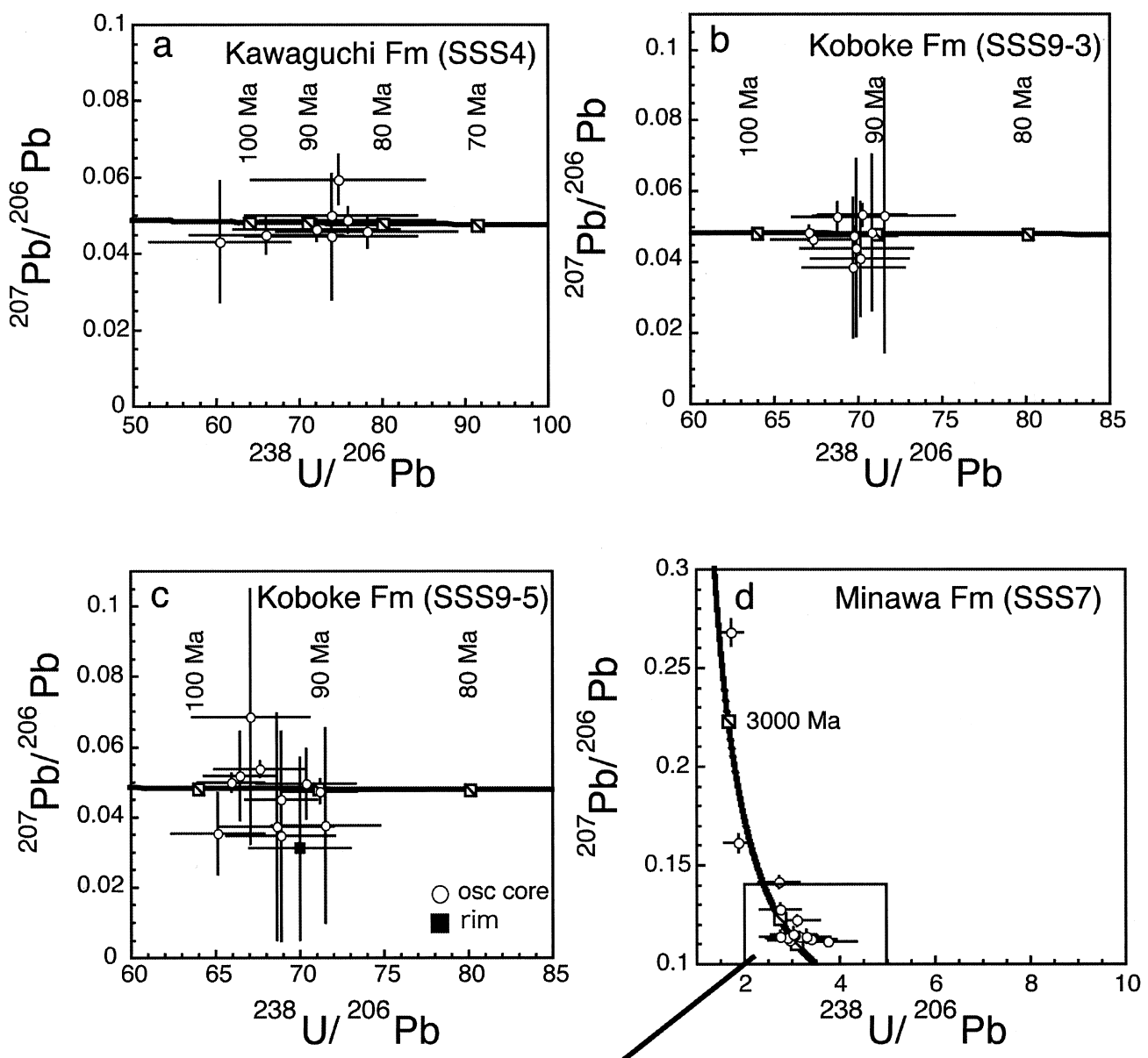

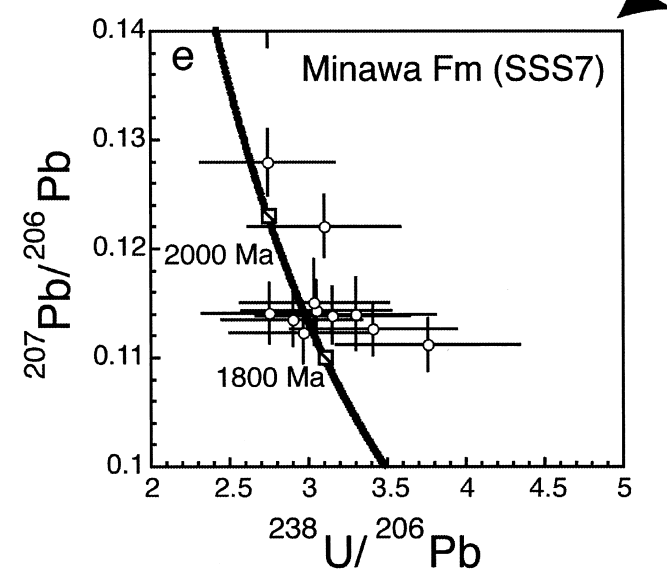

Fig. 3. Tera-Wasserburg diagram of LA-ICP-MS analyses (a-d). Error bars show two sigma. (a) Sample SSS4 (Kawaguchi Formation). (b) Sample SSS9-3 (Koboke Formation). (c) Sample SSS9-5 (Koboke Formation). (d) and (e) Sample SSS7 (Minawa Formation).

zoned parts are mostly plotted on the concordia curve in TW diagram (Fig. 3.b). All obtained U-Pb ages are identical within analytical uncertainty (Table 2 and Fig. 4), and yielded a mean age of $92 \pm 4 \mathrm{Ma}(2 \sigma)$. Analyzed zircons have $\mathrm{Th} / \mathrm{U}$ ratios in the range from 1.88 to 3.44 (Fig. 5). These ages are restricted in a limited narrow range as expected by its occurrence.

Twelve spots were analyzed from ten zircon grains of the granite porphyry cobble (SSS9-5). The data are mostly concordant (Fig. 3.c). These yield U-Pb ages ranging from 100 to $87 \mathrm{Ma}$ (Table 2, Fig. 4) and have high Th/U ratios between 1.06 and 2.16 (Fig. 5). The mean age is $94 \pm 4 \mathrm{Ma}(2 \sigma)$. This age is very close to that of the former clast (SSS9-3) from the same conglomerate bed. These clasts seem to be provided from the common igneous provenance.

\section{Minawa Formation}

Fourteen spots were analyzed for thirteen zircon grains from the psammitic schist (SSS7). The zircons yielded U$\mathrm{Pb}$ ages between 3300 and 1800Ma (Table 1 and Fig. 3.d, 


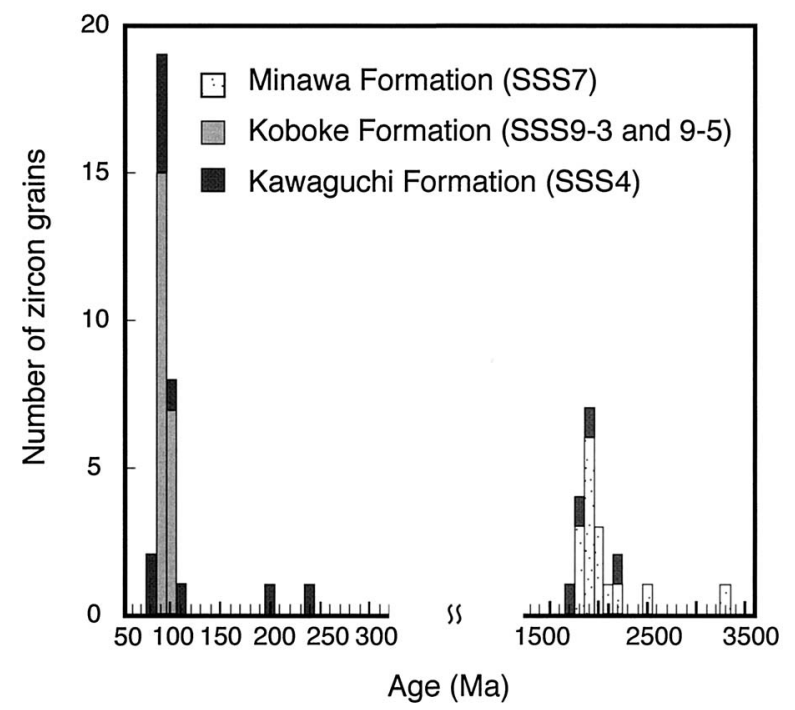

Fig. 4. Histograms of the apparent ${ }^{206} \mathrm{~Pb} /{ }^{238} \mathrm{U}$ ages $(300-50 \mathrm{Ma})$ and ${ }^{200} \mathrm{~Pb} / 206 \mathrm{~Pb}$ ages $(3500-1500 \mathrm{Ma})$ of zircons of each formation in the Oboke area.

3.e). Ten spots are clustered at 1.9-1.8 Ga (Fig. 4). The Th/U ratios were $0.41-2.86$ (Fig. 5). These higher Th/U ratios exceeding 0.1 as well as oscillatory zoning structure indicate that the analyzed zircons are of igneous origin. It should be noted that these zircons are detrital in origin as well as those of the Kawaguchi Formation, but their source was probably dominated by the $1.9-1.8 \mathrm{Ga}$ igneous rocks and had clearly different characteristics from that of the Kawaguchi Formation.

\section{Discussions}

\section{Bottom boundary of the Sanbagawa belt}

The U-Pb ages of zircon grains from the igneous cobbles in the Koboke Formation show $92 \pm 4 \mathrm{Ma}$ and $94 \pm 4 \mathrm{Ma}$. Manabe et al. (1996) reported zircon TIMS ages between 110 and $96 \mathrm{Ma}$ from the igneous conglomerates in the same region. Our data are younger than them. From the Kawaguchi Formation at the structural bottom in this area, slightly younger igneous zircons clustered in the range between 100-80 Ma were obtained, and the youngest U-Pb age was $82 \pm 11$ Ma. Much older zircons showing a wide spectrum from 2100 to $200 \mathrm{Ma}$ are also present in the Kawaguchi Formation. Because the protolith of the Kawaguchi Formation is sedimentary rocks, such zircons must have been supplied from the hinterland including older igneous rocks than the Cretaceous age.

As the zircon ages are of igneous age, the depositional ages for the Koboke and Kawaguchi Formations should be younger than their youngest zircon ages, i.e. $92 \pm 4$ and $82 \pm 11 \mathrm{Ma}$, respectively. For the Koboke Formation, metamorphic ages of $77-63$ Ma have been given based

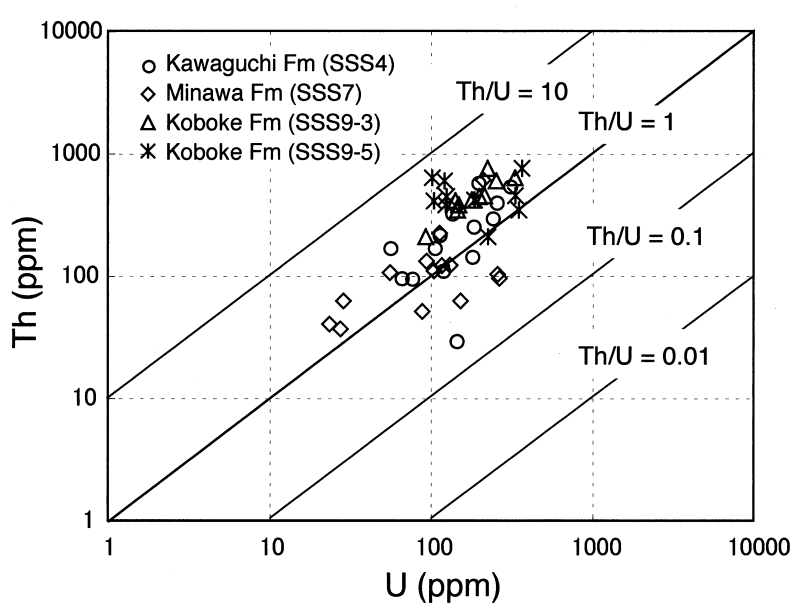

Fig. 5. U-Th relations for all analyzed spots. The diagonal lines show $\mathrm{Th} / \mathrm{U}$ ratios for reference.

on $\mathrm{K}$-Ar ages of fine-grained phengitic micas from pelitic and psammitic schists (Itaya and Takasugi, 1988) and whole rock Ar-Ar ages of psammitic schist (Takasu and Dallmeyer, 1990). Therefore, the depositional age of the Koboke Formation is confined between 92 and 77 Ma. Takahashi (1983) summarized the space-time distribution of magmatism in eastern Asia from late Mesozoic to early Cenozoic and showed an extensive volcano-plutonic activity along the $1500 \mathrm{~km}$ long continental arc of the eastern margin of the Asia from $130 \mathrm{Ma}$ to $70 \mathrm{Ma}$. Its activity supplied much amount of volcanogenic materials to the trench. The depositional age of the Koboke Formation between 92 to $77 \mathrm{Ma}$ is consistent with the volcano-plutonic history of the eastern Asia.

On the contrary, zircons from the Minawa Formation (the main Sanbagawa belt) show remarkably older ages (3300 to $1800 \mathrm{Ma}$ ) than the other two formations. The age difference suggests the different source of sedimentary clasts. Okamoto et al. (2004) reported U-Pb SHRIMP age for zircons from the eclogite facies rocks from the Sanbagawa belt. The zircons from a sedimentary-origin eclogite exhibit detrital cores with metamorphic rims. Most core ages range from 148 to 134 Ma but one age indicates $>$ 1900 Ma. They concluded that such Palaeoproterozoic zircons are detrital in origin and were supplied into sediments in the southwest Japan prior to the Miocene opening of the Japan Sea. Bruguier et al. (1997) reported that the basement rocks of the North China (Sino-Korean) Craton is predominated by 2000-1800 Ma. During the period of 240-220 Ma, the North China Craton collided against the South China (Yangtze) Craton to form a suture zone named the Dabie-Sulu HP-UHP belt, which may have provided huge sedimentary flux to the Paleo-Pacific ocean near Japan (Maruyama, 1997). Sano et al. (2000) also 


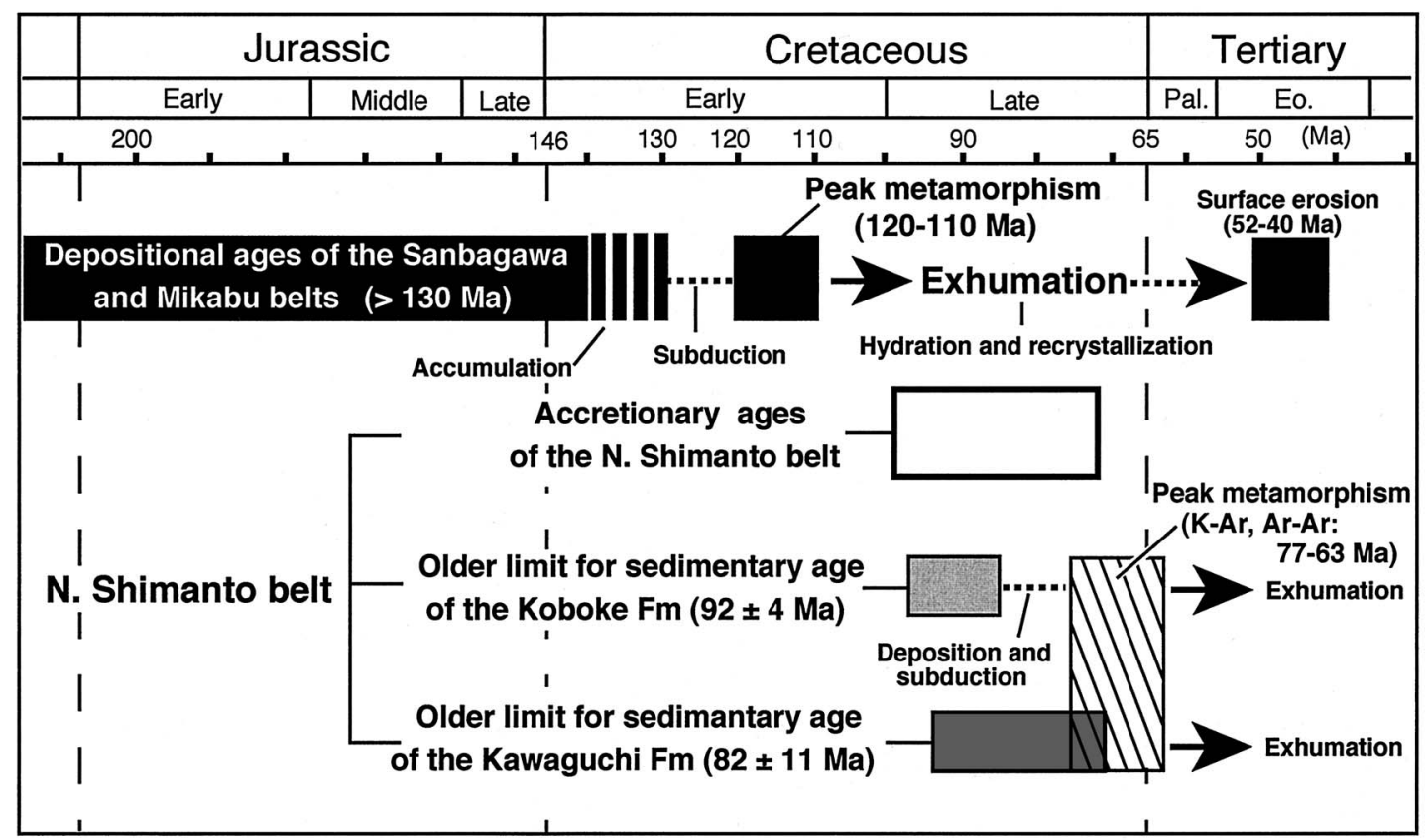

Fig. 6. Chronological summary of the Sanbagawa belt, the Northern Shimanto belt, the Mikabu belt, the Koboke Formation and the Kawaguchi Formation. Depositional ages of the Sanbagawa and Mikabu belts are taken from Matsuda (1978), Suyari et al. (1980), Iwasaki et al. (1984), Isozaki and Itaya (1990), Matsuoka (1999) and Okamoto et al. (2004). Sanbagawa metamorphic ages are taken from Minamishin et al. (1979), Suzuki et al. (1990) and Okamoto et al. (2004). The K-Ar and Ar-Ar ages refer to Itaya and Takasugi (1988) and Takasu and Dallmeyer (1990). Accretionary ages of the Northern Shimanto belt refer to Taira et al. (1982) and Kiminami et al. (1998; 1999). The ages of surface erosion of the Sanbagawa belt refer to Isozaki and Itaya (1990).

reported ca. 2000 Ma SHRIMP II U-Pb ages for detrital zircons from the Jurassic Kamiaso conglomerates and from the Hida gneisses in central Honshu. The Hida gneissses are considered to have been extension portion of the Dabie-Sulu UHP belt and comprised the continental margin when the protolith of the Sanbagawa metamorphic rocks were accumulated at the trench (e.g. Isozaki and Maruyama, 1991; Maruyama, 1997; Maruyama et al., 1997). The Palaeoproterozoic age is quite consistent with the igneous zircon ages from the Minawa Formation in the present study. Therefore, it suggests that the protolith sediments of the Sanbagawa metamorphic rocks were supplied from a hinterland including the North China Craton.

The Sanbagawa belt is tectonically overlain by the Mikabu belt (Takeda et al., 1977). It is thought that the Mikabu belt was metamorphosed under the pumpellyite-actinolite, greenschist and bluecschist facies conditions (Maruyama and Liou, 1985; Banno and Sakai, 1989). The Triassic conodonts have been reported from metacarbonate in the southern end of the Sanbagawa belt (Matsuda, 1978; Suyari et al., 1980). The latest Jurassic radiolarians have been reported from red volcanic phyllite and red shale from the Mikabu belt in eastern Shikoku and Kanto
Mountain (Iwasaki et al., 1984; Matsuoka, 1999). The youngest detrital zircon of the Sanbagawa schists is $140-$ 130 Ma which have been reported from Okamoto et al. (2004). These facts strongly indicate that both the Sanbagawa and Mikabu belts were formed as accretionary complex at trench during the latest Jurassic to the earliest Cretaceous: presumably ca. 130 Ma.

The age of the Sanbagawa metamorphism has a long history of study. It has been well summarized by Isozaki and Itaya (1990). Major contribution was done by Itaya and Takasugi (1988) who showed the systematic measurement of K-Ar age for phengite along a NS traverse of the Sanbagawa belt in Shikoku, ranging from 90 to $63 \mathrm{Ma}$. These age spectra were also confirmed by Takasu and Dallmeyer (1990). Because their K-Ar and Ar-Ar ages are cooling age, the peak metamorphic age must have been much older than 90 Ma. A metamorphic age of the Sanbagawa eclogite $(120-110 \mathrm{Ma})$ has been reported by Okamoto et al. (2004) who dated U-Pb SHRIMP zircon age from the quartz-bearing eclogite at the boundary between the Higashi-Akaishi peridotite and the Iratsu eclogite. A Rb-Sr whole rock isochron age obtained by Minamishin et al. (1979) from high-grade pelitic schists suggests that the peak metamorphism occurred at $116 \pm 10 \mathrm{Ma}$. Suzuki et 
al. (1990) reported $\mathrm{K}$-Ar ages ranging in 129-112 Ma from the phengitic micas in low-grade rocks formed below the closure temperature of K-Ar system. These data suggest the peak metamorphic age of 120-110 Ma. Consequently, the Sanbagawa metamorphism can be defined as the high-P/T metamorphism recorded in the SW Japan, with peak metamorphic ages of Early Cretaceous, and with cooling ages of Late Cretaceous.

The history of the Sanbagawa belt can be summarized as below. The accretionary complex was formed by subduction of the pre-Triassic oceanic lithosphere with ocean plate stratigraphy. The Triassic-Jurassic deep ocean sediments and earliest Cretaceous hemipelagite on the MORB crust subducted into mantle from trench together with trench turbidite by ca. $130 \mathrm{Ma}$. The whole package of the sequence subducted and was metamorphosed in ca. 120$110 \mathrm{Ma}$, and the highest-grade portions suffered the eclogite facies metamorphism at the depths over $70 \mathrm{~km}$. We, thus, define the Sanbagwa belt as the accretionary complex formed at 140-130 Ma, and metamorphosed at $120-110 \mathrm{Ma}$ in the deep subduction zone.

At the period around 120-110 Ma, the protolith of the Koboke and Kawaguchi Formations had not yet been formed. Deposition of the Northern Shimanto belt must have taken place from late Early Cretaceous to Late Cretaceous, according to the fossil age constraints in Shikoku (Taira et al., 1982; Kiminami et al., 1998; 1999). The zircon ages reported herein from the Koboke Formation and its Ar-Ar ages (Takasu and Dallmeyer, 1990) indicate the deposition age of during 92-77 Ma. These ages are definitely younger than the Sanbagawa metamorphic age (120-110 Ma) and correspond to the depositional ages of the Northern Shimanto belt (Fig. 6). As mentioned above, the LA-ICP-MS zircon U-Pb ages suggest that zircon age of the Kawaguchi Formation $(82 \pm 11 \mathrm{Ma})$ may be slightly younger than those of the structurally overlying Koboke Formation (92 $\pm 4 \mathrm{Ma})$. However, this does not mean that the accretion of the Kawaguchi Formation was subsequent to the Koboke Formation. Yet the structural relationship between those two formations suggests the earlier accretion of the Koboke Formation than the underplated Kawaguchi Formation.

Kiminami et al. (1999) reported the XRF analyses of Jurassic-Cretaceous sandstones covering the Inner and Outer zones of SW Japan and suggested that the Koboke psammitic and conglomeratic schists have a compositional similarity to the Northern Shimanto belt in eastern Shikoku (Hiwasa Formation). Depositional age of the Hiwasa sandstone is considered as Late Cretaceous (Campanian: 84-74 Ma), based on fossil ages and lithostaratigraphy (Kiminami et al., 1998). Our study with the depositional age of the Koboke Formation between 92 to $77 \mathrm{Ma}$ is very consistent with their result.

We conclude that the ascription of the Koboke and Kawaguchi Formations is to the Northern Shimanto belt and the boundary between the Sanbagawa and the Northern Shimanto belts must be placed between the Minawa Formation and the underlying Koboke Formation (Fig. 7). Although the kinematic nature of the fault boundary has not yet been determined, the overlying unit, i.e. the Sanbagawa belt record definitely higher-P (greater depth) than the underlying unit, i.e. the Northern Shimanto belt, suggesting the boundary as a thrust fault in origin. The equivalent tectonic boundary was confirmed in central Kii Peninsula (Sasaki and Isozaki, 1992; Masago et al., 2005) (Fig. 8.a). According to them, it was a thrust fault with a top-to-the-south sense, by which the Sanbagawa belt equivalent to the Minawa Formation overlies the Northern Shimanto belt (Koboke Formation equivalent).

In central Shikoku, Kawato et al. (1991) and Masago et al. (2005) identified the upper boundary of the Sanbagawa metamorphic rocks as a normal fault, by which a nonmetamorphic unit overlies a metamorphic unit within the Jurassic Chichibu belt (Fig. 8.b). The sense of the fault movement was estimated to be top-to-the-north (Masago et al., 2005) in contrast to the bottom boundary thrust fault.

\section{Spacial distribution of the Sanbagawa metamor- phism}

The Japanese Islands consist fundamentally of accretionary complex from late Paleozoic to Cenozoic that formed in a subduction zone. Hence geotectonic subdivision of the Japanese island has been based on formation age of individual accretionary complex, and named it as "belt" which shares a same time span of formation age. Whereas, metamorphic belts have been traditionally treated as an independent geologic unit, even though they have the same accretionary ages with the unmetamorphic units. There is a problem associated with this geotectonic subdivision. It is duality of definition of the belt. The duality of definition caused the ambiguity of tectonic division, particularly on the transition from lower grade to unmetamorphosed rocks.

In central Shikoku, from north to south, the Ryoke, Sanbagawa, Mikabu, Chichibu, Sanbosan and Shimanto belts are arrayed parallel. It is noteworthy that the Sanbagawa, Mikabu and Sanbosan belts share the same accretionary age. The accretionary age of the Sanbagawa and Mikabu belts have already mentioned above. The accretionary age of the Sanbosan belt is from latest Jurassic to earliest Cretaceous which has been reported from Matsuoka et al. (1998). On the other hand, the Sanbagawa and Mikabu 


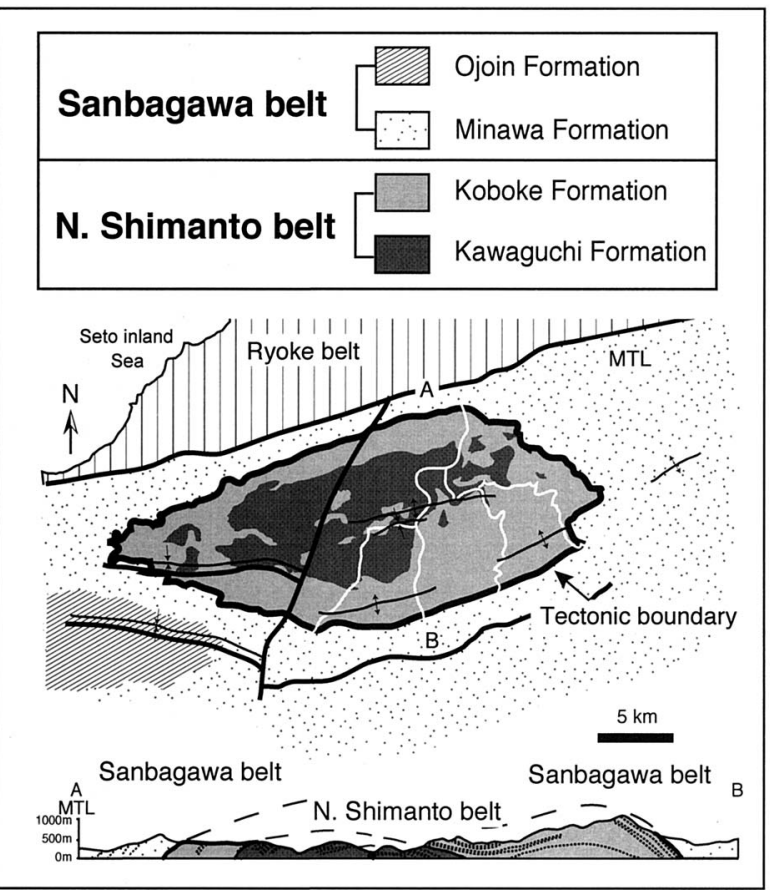

Fig. 7. A new tectonic division of the Oboke area in central Shikoku (modified after Kojima and Mitsuno, 1966; Kenzan Research Group, 1984). Legends are same as Fig. 1. belts including a northernmost part of the Chichibu belt show the same metamorphic age. The radiometric isotope ages (K-Ar and/or Ar-Ar ages) range from 98 to $96 \mathrm{Ma}$ (Mikabu belt; Dallmeyer et al., 1995), and range from 129 to $105 \mathrm{Ma}$ (Chichibu belt; Suzuki et al., 1990; Kawato et al., 1991). The metamorphic age of the Sanbosan belt has not yet been understood. The Sanbosan belt was metamorphosed under the prehnite-pumpellyite to zeolite facies. Thus, we infer the possibility that the metamorphism of the Sanbosan belt occurred in the same age spectrum of the Sanbagawa and Mikabu belts.

The tectonic superposition and spacial distribution of the Sanbagawa metamorphism are summarized as follows (Fig. 9). The latest Jurassic-earliest Cretaceous accretionary complex (here termed as the Sanbagawa metamorphic units) suffered the Sanbagawa metamorphism. The higher-grade portion is called as the Sanbagawa belt, while the lower-grade part called the Mikabu belt together with a part of the Chichibu belt and the lowest-grade portion as the Sanbosan belt. The metamorphic grade relatively decreases from north to south. The both top and bottom boundaries of the Sanbagawa metamorphic units are sub-horizontal faults. The highest-grade part of the

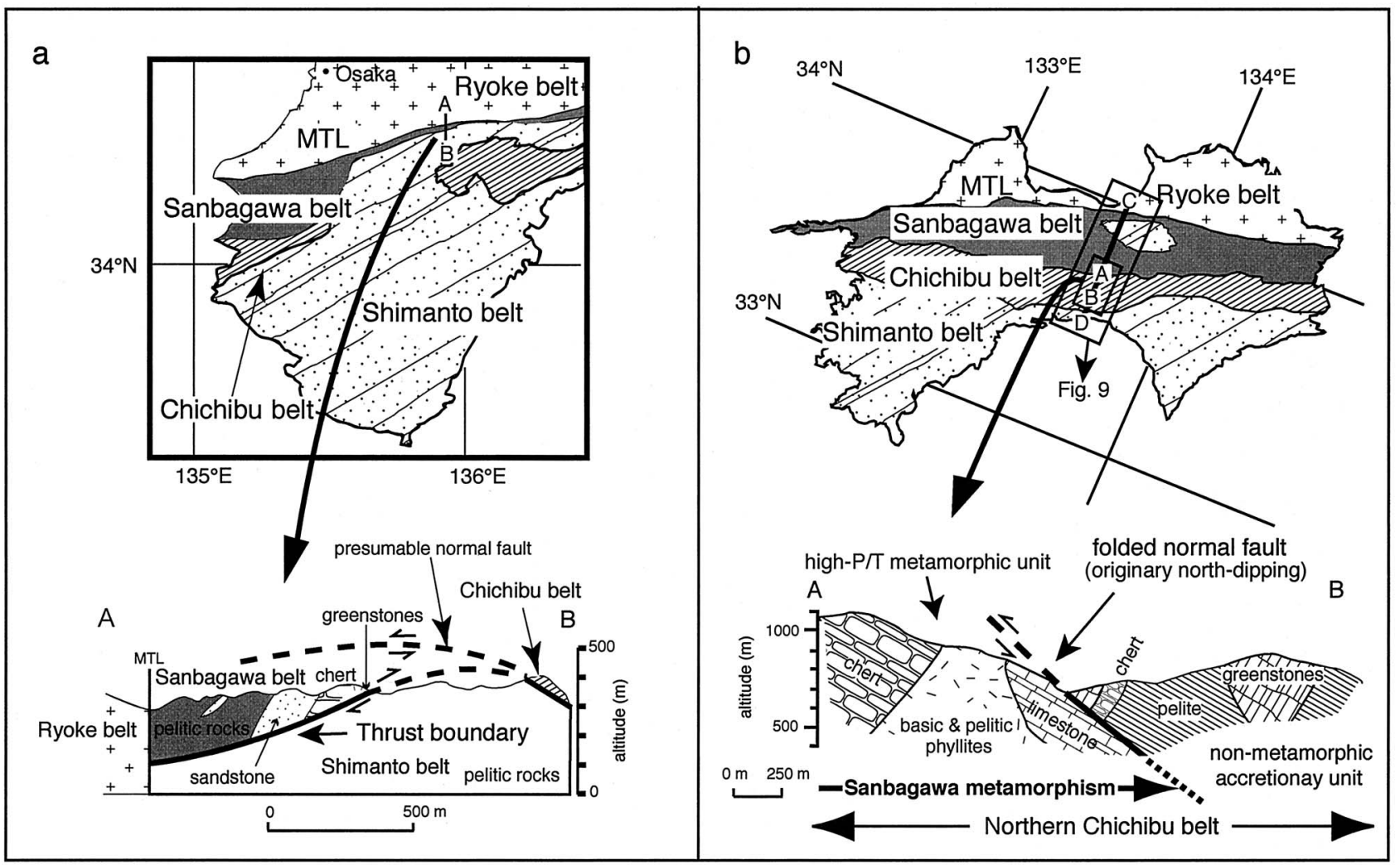

Fig. 8. (a) Index map and geological profile of the thrust boundary between the Sanbagawa belt and the Shimanto belt in central Kii Peninsula (modified after Masago et al., 2005). (b) Index map and geologic profile of the tectonic boundary between the metamorphosed Chichibu belt by the Sanbagawa metamorphism and the Chichibu belt (Jurassic accretionary complex) in central Shikoku (modified after Kawato et al., 1991). MTL: Median Tectonic Line. 


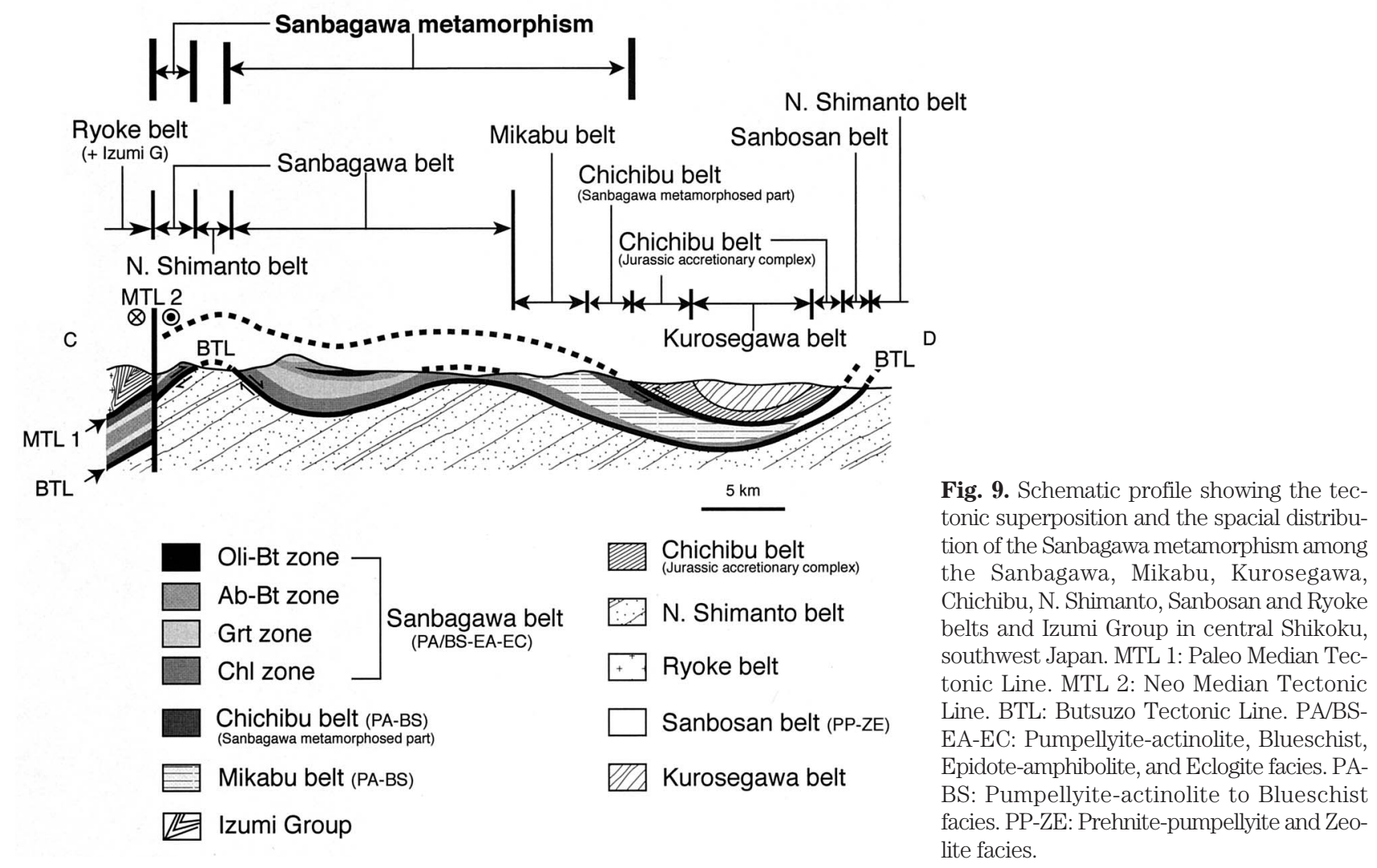

Sanbagawa belt was situated in the structurally intermediate level, and is wrapped by the lower-grade rocks (Banno and Sakai, 1989; Ota et al., 2004).

The Sanbagawa metamorphic units occur as sandwiched between the overlying Jurassic Chichibu belt and the underlying Cretaceous Northern Shimanto belt, and its thickness is less than $4 \mathrm{~km}$. The top and bottom boundaries of the Sanbagawa metamorphic units were gently deformed to show antiforms, symforms and dome in central Shikoku, and was cut by high-angle secondary normal faults in several places (Figs. 7, 9). Hence, these Sanbagawa metamorphic units were deformed together with surrounding units after the tectonic juxtaposition at the mid-crustal levels. The P-T condition of juxtaposition is estimated by the metamorphic recrystallization at the pumpellyite-actlinolite facies to the blueschist facies by the metamorphic mineral assemblages in the underlying Shimanto belt (Banno and Sakai, 1989; Sakaguchi, 2003).

The bottom boundary of the Sanbagawa metamorphic units is considered to be northern extension of the $\mathrm{Bu}$ tsuzo Tectonic Line (B.T.L). The B.T.L was defined as a boundary between the Sanbosan and N. Shimanto belts (e.g. Murata, 1982) (Fig. 9). Recently, a seismic survey across the eastern Shikoku of the Outer zone of Southwest Japan revealed that the Median Tectonic Line (M.T.L 1) dips northward at about 30 degrees, and reach- es to the MOHO depth (Sato et al., 2005). According to their results, the bottom boundary of the Sanbagawa metamorphic units also reaches to the MOHO depth. If the Sanbosan belt is equivalent to the Sanbagawa belt, the boundary between the Minawa Formation (Sanbagawa belt) and the Koboke Formation (N. Shimanto belt) must be the equivalent to the B.T.L., which is thus considered to continue from surface to the MOHO depth.

\section{Conclusions}

1) The U-Pb LA-ICP-MS ages of igneous zircon grains separated from igneous cobbles and psammitic scshits indicate that both the Koboke and Kawaguchi Formations belong not to the Sanbagawa belt but to the Northern Shimanto belt.

2) The bottom boundary of the Sanbagawa belt is present between the Koboke and the Minawa Formations.

3) The Sanbagawa and Mikabu belts, and the northernmost part of the Northern Chichibu belt were formed at the same time as an accretionary complex and subjected a series of subduction zone metamorphism. These belts had been metamorphosed at different levels. The Sanbagawa belt suffered peak metamorphism ranging from the pumpellyite-actinolite/blueschist and epidote-amphibolite to eclogite facies, whereas the Mikabu belt and the northernmost part of the Chichibu 
belt were subjected to the blueschist and pumpellyiteactinolite facies. The Sanbosan belt was metamorphosed at the lowest grade, the zeolite to prehnitepumpellyite facies.

\section{Acknowledgments}

We appreciate Dr. K. Okamoto for critical reading of an earlier version of this manuscript and thoughtful suggestions. We are grateful to Dr. S. Omori and Mr. Y. Kon for their helpful suggestions and Mr. T. Kawai for his help at fieldwork. Thanks also go to the reviewer, Professor H. Maekawa, Professor T. Itaya and Associate Professor H. Ueda by whom the manuscript was improved substantially.

\section{References}

Banno, S. and Sakai, C., 1989, Geology and metamorphic evolution of the Sanbagawa metamorphic belt, Japan. In Daly, J.S., Cliff, R.A. and Yardley, B.W.D., eds., Evolution of Metamorphic Belts, Geol. Soc. London, 43, 519-532.

Bruguier, O., Lancelot, J. R and Malavieille., 1997, U-Pb dating on single detrital zircon grains from the Triassic Songpan-Ganze flysch (Central China) : province and tectonic correlations. Earth Planet. Sci. Lett., 152, 217-231

Corfu, F., Hanchar, J. M., Hoskin P.W.O. and Kinny, P., 2003, An atlas of zircon textures. In Hanchar, J.M. and Hoskin P.W.O., eds., Zircon, Reviews in Mineralogy and Geochemistry: Mineral. Soc. America, $\mathbf{5 3}, 469-500$

Eggins, S.M., Kinsley, L.K. and Shelley, J.M.G., 1998, Deposition and element fractionation processes occurring during atmospheric pressure laser sampling for analysis by ICPMS. Applied Surface Sci., 127-129, $278-286$

Dallmeyer, R.D., Takasu, A. and Yamaguchi, K., 1995. Mesozoic tectnothermal development of the Sambagawa, Mikabu and Chichibu belts, south-west Japan: evidence from ${ }^{40} \mathrm{Ar} /{ }^{39} \mathrm{Ar}$ whole-rock phyllite ages. Jour. Metamorphic. Geol., 13, 271-286.

Hara, I., Shiota, T., Hide, K., Okamaoto, K., Takeda., K., Hayasaka, Y. and Sakurai, Y., 1990, Nappe structure of the Sambagawa belt. Jour. Metamorphic. Geol., 8, 441-456.

Hirata, T., lizuka, T. and Orihashi, Y., 2005, Reduction of mercury background on ICP-mass spectrometry for in situ U-Pb age determinations of zircon samples. Jour. Anal. At. Spectrom., 20, 696-701.

Hoskin, P.W. and Black, L.P., 2000, Metamorphic zircon Formation by solid-state recrystallization of protolith igneous zircon. Jour. Metamorphic. Geol., 18, 423-439.

lizuka, T. and Hirata, T., 2004, Simultaneous determinations of U-Pb age and REE abundances for zircons using ArF excimer laser ablationICPMS. Geochemical Jour., 38, 229-241.

Isozaki, Y. and Itaya, T., 1990, Chronology of Sanbagawa metamorphism. Jour. Metamorphic. Geol., 8, 401-411.

Isozaki, Y. and Maruyama, S., 1991, Studies on orogeny based on plate tectonics in Japan and new geotectonic subdivision of the Japanese Island. Jour. Geogr., 100, 697-761.*

Itaya, T. and Takasugi, H., 1988, Muscovite K-Ar ages of the Sanbagawa schists, Japan and argon depletion during cooling and deformation. Contrib. Mineral. Petrol., 100, 281-290.

Iwasaki, M., Ichikawa, K., Yao, M. and Faure, M., 1984, Age of greenstone conglomerate of the Mikabu Greenstone, eastern Shikoku. Proceedings of the Kansai branch, Geol. Soc. Japan, 97, 21.**

Kawato, K., Isozaki, Y. and Itaya, T., 1991, Geotectonic boundary between the Sanbagawa and Chichibu belts in central Shikoku, Southwest Japan. Jour. Geol. Soc. Japan, 97, 959-975.*

Kenzan Research Group, 1984, Stratigraphy and geologic structure of the
Sambagawa metamorphic belt in the Oboke area, central Shikoku, Japan. Earth Sci., 38, 53-63.*

Kiminami, K., Hamasaki, A. and Matsuura, T., 1999, Geochemical contrast between the Sanbagawa psammitic schists (Oboke unit) and the Creatceous Shimanto sandstones in Shikoku, Southwest Japan and its geologic significance. Island. Arc, 8, 373-382

Kiminami, K., Matsuura, T., Iwata, T. and Miura, K., 1998, Relationship between sandstone composition in the Shimanto Supergroup, eastern Shikoku, and Cretaceous arc volcanism. Jour. Geol. Soc. Japan, 104, 314-326.*

Kojima, J., 1951, Stratigraphy and geological structure of the crystalline schist region in central Shikoku. Jour. Geol. Soc. Japan, 57, 177-190.

Kojima, J. and Mitsuno, C., 1966, Explanatory text of the geological map of Japan and Kawaguchi sheet (scale 1: 50,000). Geol. Surv. Japan.**

Manabe, Y., Yoshikura, S. and Gabites, J., 1996. U-Pb zircon ages for the felsic igneous cobbles in the Oboke conglomeratic schist. Abs. Jour. Geol. Soc. Japan, Annual meeting, 103, 300.**

Maruyama, S., 1997, Pacific-type orogeny revisited: Miyashiro-type orogeny proposed. Island. Arc, 6, 91-120.

Maruyama, S. and Liou, J. G., 1985. The stability of Ca-Na pyroxene in lowgrade metabasites of high-pressure intermediate facies series. Am. Min., 70, 16-2

Maruyama, S., Liou, J. G. and Terabayashi, M., 1996, Blueschists and eclogites of the world and their exhumation. Int. Geol. Rev., 38, 485594

Maruyama, S., Isozaki, Y., Kimura, G. and Terabayashi, M., 1997. Paleogeographic maps of the Japanese Islands: Plate tectonics synthesis from 750 Ma to the present. Island. Arc, 6, 121-141.

Masago, H., Okamoto, K. and Terabayashi, M., 2005, Exhumation of the Sanbagawa high-pressure metamorphic belt, SW Japan -constraints from the upper and lower boundary faults. Int. Geol. Rev., 47, 11941206 .

Matsuda, T., 1978, Discovery of Middle-Late Triassic conodont genus Metapolygnathus from calcareous schist of the Sanbagawa southern marginal belt in central Shikoku. Jour. Geol. Soc. Japan, 84, 331333.

Matsuoka, A., Yamakita, S., Sakakibara, M. and Hisada, K., 1998. Unit division for the Chichibu Composite Belt from a view point of accretionary tectonics and geology of western Shikoku, Japan. Jour. Geol. Soc. Japan, 104, 634-653.*

Matsuoka, K., 1999, Late Jurassic radiolarians from red shale on the Mikabu greenstones in the northern margin of Kanto Mountains, Japan. Earth Sci., (Chikyu Kagaku), 53, 71-74.**

Minamishin, M., Yanagi, T. and Yamaguchi, M., 1979, Rb-Sr whole rock age of the Sanbagawa metamorphic rocks in central Shikoku. Isotope Geosciences of Japanese Islands, 68-71.**

Murata, A., 1982, Large decke structures and their formative process in the Sambagawa belt-Chichibu belt, Kurosegawa and Sambosan terrains, Southwest Japan. Jour. Fac. Sci. Univ. Tokyo, sec. 2, 20, 383424

Okamoto, K., Maruyama, S. and Isozaki, Y., 2000, Accretionary complex origin of the Sanbagawa, high P/T metamorphic rocks, Central Shikoku, Japan -Layer-parallel shortening structure and greenstone geochemistry-. Jour. Geol. Soc. Japan, 106, 70-86.

Okamoto, K., Shinjoe, H., Katayama, I., Terada, K, Sano, Y. and Johnson, S., 2004, SHRIMP U-Pb zircon dating of quartz-bearing eclogite from the Sanbagawa Belt, south-west Japan: implications for metamorphic evolution of subducted protolith. Terra Nova, 16, 81-89.

Ota, T., Terabayashi, M. and Katayama, I., 2004, Thermobaric structure and metamorphic evolution of the Iratsu eclogite body in the Sanbagawa belt, central Shikoku, Japan. Lithos, 73, 95-126.

Ota, T., Terabayashi, M., Parkinson, C. D. and Masago, H., 2000, Thermobaric structure of the Kokchetav ultrahigh-pressure high-pressure massif deduced from a north-south transect in the Kulet and SoldatKol regions, northern Kazakhstan. Island. Arc, 9, 328-357.

Sakaguchi, M., 2003, Thermal structure of pumpellyite-actinolite facies regions in the Sanbagawa belt, Shikoku, SW Japan. American Geo- 
physical Union, 2003 Fall meeting, F1531.

Sano, Y., Hidaka, H., Terada, K., Shimizu, H. and Suzuki, M., 2000, Ion microprobe U-Pb zircon geochronology of the Hida gneiss: Finding of the oldest minerals in Japan. Geochem. Jour., 34, 135-153.

Sasaki, H. and Isozaki, Y., 1992, Low-angle thrust between the Sanbagawa and Shimanto belts in central Kii Peninsula, Southwest Japan. Jour. Geol. Soc. Japan, 98, 57-60.**

Sato, H., Kojima, Y., Murata, A., Ito, T., Kaneda. Y., Onishi, M., Iwasaki, T., Oho, Y., Ogino, S., Kano, K., Kawamura, T., Kurashimo, E., Koshiya, S., Takasu, A., Takeshita, T., Tsumura, N., Terabayashi, M., Toyohara, F., Nakajima, T., Noda, K., Hashimoto, Y., Hasegawa, S., Hirata, N., Miyauchi, T., Miyata, T., Yamakita, S., Yoshida, T., Harder, S., Millar, K., Kaip, G., Ozawa, T. and Ikawa, T., 2005, Crustal Structure of the Outer Zone in Sourth west Japan revealed by Shikoku and SetoInland-Sea Seismic Profiling in 2002. Bull. Earthq. Res. Inst. Univ. Tokyo, 80, 53-71.*

Shibata, K., Sugiyama, Y., Takagi, H. and Uchiumi, S., 1988, Isotopic ages of rocks along the Median Tectonic Line in the Yoshino area, Nara Prefecture. Bull. Geol. Surv. Japan, 39, 759-781.*

Suyari, K., Kuwano, Y. and Ishida, K., 1980, Discovery of the Late Triassic conodonts from the Sambagawa Metamorphic Belt proper in western Shikoku. Jour. Geol. Soc. Japan, 86, 827-828.**

Suzuki, H., Isozaki, Y. and Itaya, T., 1990, Tectonic superposition of the Kurosegawa Terrane upon the Sanbagawa Metamorphic Belt in eastern Shikoku, Southwest Japan -K-Ar ages of weakly metamorphosed rocks in northeastern Kamikatsu Town, Tokushima Prefecture-. Jour. Geol. Soc. Japan, 96, 143-153.*

Taira, A., Okada, H., Whitaker, J. H. McD. and Smith, A. J., 1982, The Shimanto Belt of Japan: Cretaceous-lower Miocene active margin sedmentation. In Legett J. K., ed., Trench-Forearc Geology: Sedimentation and Tectonics on Modern and Ancient Active Plate Margins. Geological Society Special Publication 10, 5-26.

Takahashi, M., 1983. Space-time distribution of Late Mesozoic to Early Cenozoic magmatism in East Asia and its tectonic implication. In

Hashimoto, $\mathrm{M}$ and Uyeda, S eds., Accretion Tectonics in the Circum Pacific Regions. Terra Sci. Pub. Tokyo, 69-88,

Takasu, A. and Dallmeyer, R. D., $1990,{ }^{40} \mathrm{Ar} /{ }^{39} \mathrm{Ar}$ mineral age constraints for the tectonothermal evolution of the Sanbagawa metamorphic belt, central Shikoku, Japan: a Cretaceous accretionary prism. Tectonophysics, 185, 111-139.

Takeda, K., Tsukuda, E., Tokuda, M. and Hara, I., 1977, Structural relationship between the Sambagawa and Chichibu Belt. In Hide, K. ed., The Sambagwa Belt. Hiroshima Univ. Press, Hiroshima, 107-151.*

Terabayashi, M., Okamoto, K., Yamamoto, H., Kaneko, Y., Ota, T., Maruyama, S., Katayama, I., Komiya, T., Anma, R., Ozawa, H., Windley, B. and Liou, J.G., 2004, Accretionary complex origin of the mafic-ultramafic bodies of the Sanbagawa belt, central Shikoku, Japan. Int. Geol. Rev., 47, 1058-1073.

Terabayashi, M., Maruyama, S. and Liou, J. G., 1996, Thermobaric Structure of the Franciscan Complex in the Pacheco Pass Region, Diablo Range, California. Jour. Geol., 104, 617-636.

Tunheng, A. and Hirata, T., 2004, Development of signal smoothing device for precise elemental analysis using laser ablation-ICP-mass spectrometry. Jour. Anal. At. Spectrom., 19, 932-934.

* in Japanese with English abstract ** in Japanese

\section{用語対比}

Ojoin Formation

Kawaguchi Formation

Koboke Formation

Minawa Formation

Besshi

Oboke

大生院層
川口層
小歩危層
三縄層
別子
大歩危

大生院層

三縄層

大歩危

(要 旨)

Aoki, K., Iizuka, T., Hirata, T., Maruyama, S. and Terabayashi, M., 2007, Tectonic boundary between the Sanbagawa belt and the Shimanto belt in central Shikoku, Japan. Jour.Geol.Soc.Japan, 113, 171-183. （青木一勝・飯塚 毅・平田岳史・丸山 茂徳・寺林 優, 2007, 四国中央部, 三波川帯と四万十帯のテクトニクス境界. 地質雑, 113, $171-183)$

四国中央部大歩危地域に分布する三波川結晶片岩類は，原岩層序に基づき構造的上位か ら下位に向かい三縄層，小歩危層，川口層に分類されてきた。今回，それぞれの層から火 成ジルコンを分離し, LA-ICP-MS を用いて U-Pb 年代測定を行った結果, 三縄層中のジル コンの多くが 1900-1800 Ma の火成年代を示した。一方，小歩危層・川口層中のジルコン から得られた火成年代は三縄層よりも若く，その中で最も若い年代は，それぞれ $92 \pm 4$ $\mathrm{Ma}, 82 \pm 11 \mathrm{Ma}$ であった. 両層の堆積年代は更に若く，その年代は，四万十帯北帯の付 加年代と一致する。このことから，従来，三波川帯と見なされてきた小歩危層，川口層は， 四万十帯北帯であることが明らかになった。したがって，三縄層と小歩危層の層境界は， 三波川帯／四万十帯境界にあたる。また，大歩危地域における構造的累重関係は，三波川 変成帯が四万十帯の構造的上位に位置することを示している。 